\title{
THE ROLE OF REGION-SPECIFIC INSTITUTIONALIZED CULTURAL CHARACTERISTICS ON INCOME INEQUALITY IN THE AMERICAN SOUTH: THE CASE OF GEORGIA'S PLANTATION BELT
}

\author{
William B. Levernier*
}

\begin{abstract}
Numerous studies have attempted to determine which factors affect income inequality in a given region. These factors relate to the demographic, economic, educational, and labor force characteristics of the region. One factor that has largely been ignored in the previous literature, however, is the effect of long-established, region-specific institutionalized social and cultural characteristics. By estimating the effect of a county's location in Georgia's Plantation Belt, a region whose historical and economic development differs substantially from the rest of the state, this paper addresses the role that these institutionalized cultural characteristics play in the determination of income inequality in the state of Georgia. The results indicate that while demographic, economic, educational, and labor force characteristics significantly affect income inequality in Georgia, income inequality is greatest in the Plantation Belt counties. In addition, the racial composition of a county has a much weaker effect on income inequality in Plantation Belt counties than in those counties located outside the Plantation Belt.
\end{abstract}

\section{INTRODUCTION}

The purpose of this paper is to ascertain the extent to which family income inequality in a given region is affected by various demographic, economic, educational, labor force, and locational characteristics of the region. The previous literature has examined the role of many demographic, economic, educational, and labor force characteristics. Heretofore, however, most of the literature has ignored the effect that region-specific institutionalized social and cultural characteristics have on income inequality. Different geographic regions experience different patterns of historical and economic development, which affect the current social and cultural characteristics of the region. These social and cultural characteristics, which are constant within a region but vary across regions, are likely to affect the current economic characteristics of a region, such as the distribution of income. The primary focus of this paper is to extend the previous literature by determining the effect that region-specific institutionalized social and cultural characteristics, proxied by whether or not a county in Georgia is located within Georgia's Plantation Belt, have on family income inequality in a county. This paper also deter-

\footnotetext{
*Associate Professor of Economics, Georgia Southern University, Statesboro.
} 
mines whether one of the demographic characteristics, the racial composition of the county's population, has a stronger effect on family income inequality in counties in the Plantation Belt than in counties located outside the Plantation Belt.

Most of the characteristics mentioned above are found to significantly affect a county's income inequality in this study. Factors such as the location of the county, the percentage of the county's population that is black, the percentage of the county's families that are headed by a female, the educational characteristics of the county's population, the percent of the county's working population that is employed in manufacturing, and the employment rate in the county are all found to significantly affect a county's level of income inequality, supporting the findings of much of the previous literature. In addition, counties with a relatively large black population that are located in the Plantation Belt are found to have a more equal income distribution than counties with an equally large black population that are located outside the Plantation Belt, ceteris paribus.

\section{REVIEW OF THE PREVIOUS LITERATURE}

Previous research on income inequality has shown both Georgia and the South to have a relatively high degree of income inequality. Braun (1988), for example, ranked Georgia 45th, employing the Gini coefficient to measure income inequality. Using seven alternative measures of income inequality, he found that Georgia ranked between 40th and 46th. Husted (1991), in a comparison of statelevel income inequality, found Georgia to be ranked 36th in terms of its Gini coefficient. He also found Georgia to be one of 38 states that had increasing inequality between 1981 and 1987. Gunther and Leathers (1975), in an analysis of income inequality during the $1950-1970$ period, found evidence that family income is distributed less equally in the South than in other regions of the United States. Levernier, Partridge, and Rickman (1995) found that Georgia, and most other Southern states, consistently ranked in the bottom third of all states during the $1960-1990$ period.

The prior literature on income inequality has extensively examined the effect of various demographic characteristics on the distribution of income. Several studies have included a measure of the racial composition of the area under consideration. This variable has taken the form of the percent of the population that is white (Aigner and Heins 1967), the percent of the population that is nonwhite (Braun 1988, Durden and Schwarz-Miller 1982, Farbman 1973, and Rice and Sale 1975), and the percent of the population that is black (Brem, Durden, and Gaynor 1989). Generally, these studies have found that income inequality in an area increases as the percent of the population in the area that is black or nonwhite 
increases. In addition, another demographic factor that may potentially affect income inequality is the percent of families headed by a female (with no husband present). Because female-headed households are disproportionately low-income households, it is expected that income inequality will increase as the percent of families that are female-headed increases. Evidence supporting this hypothesis has been found by several researchers (Brem, Durden, and Gaynor 1989; Durden and Schwarz-Miller 1992; Levernier, Rickman, and Partridge 1995; Long, Rasmussen, and Haworth 1977; and Partridge, Rickman, and Levernier 1996).

The effect of an urban/rural population on income inequality has also been examined in several previous studies, but the findings have been mixed. Aigner and Heins (1967), Braun (1988), and Brem, Durden, and Gaynor (1989) found the percent of the population that lives in urban areas within a region to have a generally insignificant effect on the region's level of income inequality. Rice and Sale (1975), though, found the percent of a Louisiana parish's population that is rural to have a positive effect on the parish's level of income inequality in 1960, but to have a statistically insignificant effect in 1950 and 1970. Farbman (1973), in a study of income inequality at the county/parish level in thirteen southern states, found the percent of a county/parish's population that lives in rural areas to have a statistically significant effect in two of the thirteen states. Levernier, Partridge, and Rickman (1995) found the percent of a state's population that resides in metropolitan areas to have a weak or statistically insignificant effect on income inequality in 1960,1970,1980, and 1990. Renkow (1996), in a study of rural/urban earnings differentials in North Carolina over the 1970-1990 period, found the effect of several factors on a person's labor force earnings to be substantially different in rural counties than in urban counties.

The educational characteristics of an area's population are generally found to affect the level of income inequality in the area. Aigner and Heins (1967), Braun (1988), Brem, Durden, and Gaynor (1989), Rice and Sale (1975), and Farbman (1973) found that an area's level of income inequality decreases as the mean or median educational attainment of its population increases. In addition, Brem, Durden, and Gaynor (1989) found that as the percent of the population in an area having eight or fewer years of education increases, income inequality in the area increases. Braun (1988) further found that a state's income inequality increases as the standard deviation of the educational attainment of its population increases.

The per capita income of a region, a proxy for the level of economic development, has long been postulated to affect income equality in a region [Kuznets (1955)]. The empirical findings regarding the effect of an area's per capita income on its level of income inequality have been mixed, though. Several studies (Aigner and Heins, 1986, Amos 1986 and 1988, Braun 1988, Brem, Durden, and Gaynor 1989, Durden and Schwarz-Miller 1982, Rice and Sale 1975, 
and Farbman 1973) generally conclude that a region's income inequality decreases as its per capita or median income increases. Durden and SchwarzMiller (1982), however, in a study of income inequality in U.S. congressional districts, found a positive relationship between a congressional district's income and its level of income inequality, while Farbman (1973), in his study of county/parish income inequality, found per capita income and income inequality in a county or parish to be significantly and negatively related for only three of the thirteen states he examined.

Labor force characteristics have also been found to influence the distribution of income in a region. Factors such as the region's employment rate, unemployment rate, or distribution of the labor force among various industries have all been found to influence a region's income inequality in previous studies. Bradbury (1990), in a study of changes in the distribution of income during the 1980s, found that families with unemployed workers were among those most likely to become worse off during the 1979-1988 period. Aigner and Heins (1977), however, found that a state's unemployment rate does not have a statistically significant effect on its level of income equality. Braun (1988) and Durden and Schwarz-Miller (1982) found that as the employment rate of an area's population increases, its level of income inequality decreases. Aigner and Heins (1967), Braun (1988), Brem, Durden, and Gaynor (1989), Levernier, Partridge, and Rickman (1995), and Rice and Sale (1975) all found that as the proportion of a region's population employed in manufacturing or goods producing industries increases, the level of income inequality decreases. Maxwell (1989) found that as the ratio of workers employed in blue-collar occupations to white-collar occupations increases, income inequality increases, and Rice and Sale (1975) found that a region's income inequality increases as its labor force becomes more heavily employed in clerical or operative positions. In addition, Farbman (1973) found that counties/parishes that have a relatively high proportion of the population employed in mid-level occupations tend to have relatively low income inequality, ceteris paribus.

Several researchers have noted the existence of interregional differences in income inequality (Bishop, Formby and Thistle 1992; Danziger 1977; Gunther and Leathers 1975; and Nissan and Carter 1993). These interregional income inequality differences are influenced by region-specific effects, which relate to the long-established social and cultural characteristics of a region. They are characteristics, not accounted for in the previously mentioned factors, that are constant within a geographic region but that vary across regions. These region-specific institutionalized social and cultural characteristics are likely to affect income inequality in an area. 


\section{A DESCRIPTION OF THE PLANTATION BELT ${ }^{1}$}

Georgia's Plantation Belt (see Figure 1) is part of a larger Plantation Belt that includes portions of eleven different Southern states. ${ }^{2}$ The distinguishing historical characteristics of the Plantation Belt region are that during the pre-Civil War period it produced a substantial amount of cotton and had a large slave population, among the largest of all Southern states. ${ }^{3}$ In 1860 , for example, Georgia's slave population was 426,198 , second only to Virginia's (Institute of Community and Area Development 1986).

The historical and economic development of the Plantation Belt region was, in fact, much different from that of the region outside the Plantation Belt. Bartley (1990) notes that in the pre-Civil War plantation societies there were three distinct classes of people: the wealthy, land-owning class; the free class that did not own land; and slaves. Land ownership, which was highly concentrated before the Civil War, remained concentrated after the war as well. Approximately half the whites were in the class of people that did not own land, and most faced very limited economic prospects, due to an absence of employment opportunities for unskilled labor.

The plantation agriculture that developed during the period when slavery was legal continued to flourish in a modified form after the Civil War. ${ }^{4}$ The necessary ingredient for plantation agriculture is that landowners have access to a large number of unskilled workers through means other than free-functioning labor markets. ${ }^{5}$ Prior to the Civil War, the method that landowners used to obtain an adequate supply of labor was slavery. After the conclusion of the Civil War, tenant farming, or sharecropping, provided the landowners with an adequate supply of labor. In sharecropping, the tenant farmer (i.e., sharecropper) farmed land owned by someone else and received a share of the revenue obtained from the sale of his crops as payment. Under this system, the landowner provided the sharecropper with the seed and other materials necessary to farm the land at the beginning of the growing season. The sharecropper paid the landowner for the seed and other materials when the crops were sold. Because the sharecropper was unable to repay his debt to the landowner until after the crops were harvested, this arrangement effectively obligated the sharecropper to work on the land for the entire crop season. Thus, once the sharecropper committed at the beginning of the growing season to farm the land, his debt obligations prevented him from leaving the farm, even if a better economic opportunity presented itself.

If a large proportion of the sharecroppers desired to seek better paying employment before the growing season commenced, a second factor that allowed the continuance of plantation agriculture in the post-Civil War South was the absence of alternative labor opportunities for unskilled labor. This was especially 
FIGURE 1

Map of the Georgia Plantation Belt

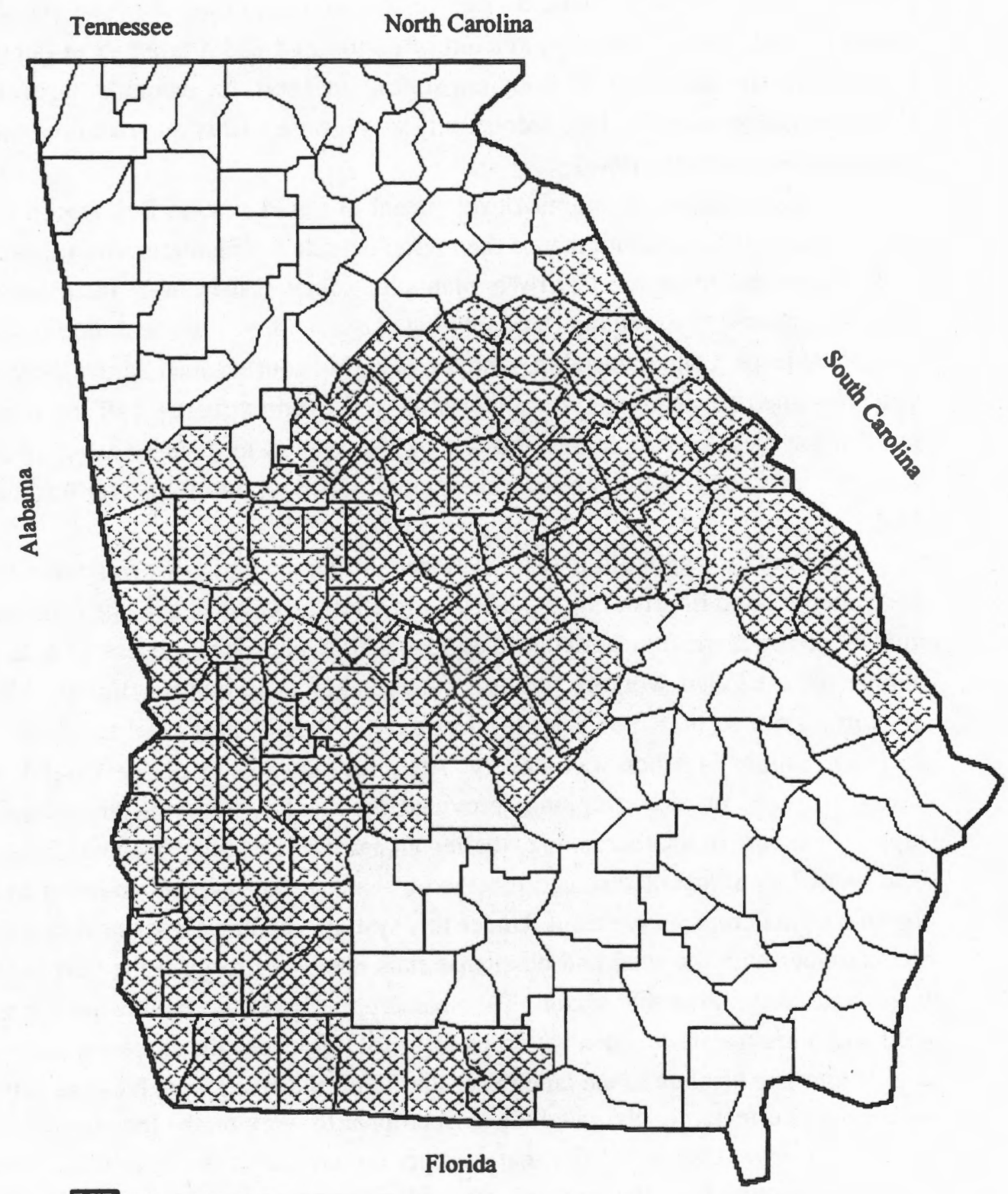

Plantation Belt 
true for Blacks, who faced discrimination even in the North (Mandle, 1978). The absence of alternative economic opportunities for unskilled workers resulted, in part, from the slow pace of industrialization in the South. Between 1890 and 1910, manufacturing employment in the United States grew by 5.6 million jobs, but grew by only 381,000 jobs in the six Southern states (Alabama, Arkansas, Georgia, Louisiana, Mississippi, and South Carolina) where plantations were most common. Also, "anti-enticement" laws, which were legal restrictions against the recruitment of agricultural laborers by Northern manufacturers, were enacted in several Southern states and worked to further restrict the economic opportunities of unskilled farm labor (Mandle 1978).

\section{A MODEL OF INCOME INEQUALITY AND THE DATA}

The measure of family income inequality used in this study is the Gini coefficient, which is constrained to take a value between 0 and 1 and where a higher value indicates a greater degree of income inequality. The Gini coefficient is approximately equal to the percentage of total family income in a county that would need to be redistributed to achieve perfect income equality among families (Card and Freeman 1994). Based on the previous discussion of the literature, I estimate the following general equation using ordinary least squares (OLS), employing 1990 data for Georgia's 159 counties.

$$
\text { GINI }_{\mathrm{i}}=\mathbf{B} \mathrm{X}_{\mathrm{i}}+\mathrm{e}_{\mathrm{i}}
$$

where $\mathrm{GINI}_{\mathrm{i}}$ is the Gini coefficient of family income inequality for the $\mathrm{i}^{\text {th }}$ county in 1989, $e_{i}$ is an error term, and $X_{i}$ is a vector of the following variables for the $i^{\text {th }}$ county.

INCOME is the average family income in the county in 1989.

BLACK is the percent of the population in the county that is black in 1990.

FEMALE is the percent of families in the county headed by a female (with no husband present) in 1990.

EDUCSTD is the standard deviation of the years of education of the 25-year-old and older population in the county in 1990.

MEANEDUC is the average years of education of the 25-year-old and older population in the county in 1990. 


\begin{abstract}
MANUFAC is the percent of the employed 16-year-old and older population in the county that is employed in manufacturing in 1990.

EMPRATE is the percent of the 16-year-old and older population in the county that is employed in 1990.

SUBURBAN is a dummy variable that indicates if the county is a suburban county in a Metropolitan Statistical Area (MSA). The variable takes a value of 1 if the county is a suburban county in an MSA. It takes a value of 0 if the county contains the central city of an MSA or if the county is not in an MSA.

PLANBELT is a dummy variable that indicates if the county is located in Georgia's Plantation Belt. The variable takes a value of 1 if the county is located in the Plantation Belt. The variable takes a value of 0 is the county is located outside the Plantation Belt.

INTPLAN is an interactive term, PLANBELT*BLACK.
\end{abstract}

Data for all variables, except SUBURBAN and PLANBELT, are from the U.S. Bureau of the Census (1990). Because the Bureau of the Census obtains income information on families for the year prior to the year the census is conducted, the value for the Gini coefficient and average family income in a particular county is for 1989 , while the value of the demographic, educational, and labor force variables are for 1990 . This situation is also faced by other researchers who study income inequality, though, and it is unlikely that it influences the results of this study.

The mean and standard deviation of the above variables, along with the family poverty rate, are reported in Table 1 . An analysis of Table 1 reveals five important distinctions between Plantation Belt counties and counties located outside the Plantation Belt. First, even though the number of counties inside the Plantation Belt is approximately the same as the number of counties outside the Plantation Belt ( 79 counties and 80 counties, respectively), the total number of families outside the Plantation Belt is nearly double the number of families that reside within the Plantation Belt. Second, counties in the Plantation Belt have a Black population that is, on average, proportionately more than twice as large as counties located outside the Plantation Belt. Third, families residing in Plantation Belt counties are more likely to be headed by a female (with no husband present) than families residing in counties located outside the Plantation Belt. Fourth, even though average family income is only slightly lower in the Plantation Belt counties, the average family poverty rate is, on average, about 3.3 percentage points 


\section{TABLE 1}

Mean and Standard Deviation for Selected Variables: All Georgia Counties, Plantation Belt Counties, and Non-plantation Beltcounties (Standard Deviations are in parenthesis)

\begin{tabular}{lrrr}
\hline \hline VARIABLE & ALL & PLAN & NONPLAN \\
\hline GINI*100 & 40.06 & 41.01 & 39.14 \\
& $(4.05)$ & $(3.93)$ & $(3.97)$ \\
INCOME & 32953.85 & 32414.99 & 33485.97 \\
& $(6691.90)$ & $(5941.82)$ & $(7357.15)$ \\
BLACK & 27.39 & 37.67 & 17.24 \\
& $(17.38)$ & $(14.89)$ & $(13.24)$ \\
FEMALE & 18.43 & 21.53 & 15.38 \\
& $(6.14)$ & $(5.90)$ & $(4.68)$ \\
EDUCSTD & 3.07 & 3.09 & 3.04 \\
& $(0.20)$ & $(0.19)$ & $(0.20)$ \\
MEANEDUC & 11.35 & 11.32 & 11.38 \\
& $(0.68)$ & $(0.66)$ & $(0.70)$ \\
MANUFAC & 26.03 & 25.89 & 26.17 \\
& $(8.24)$ & $(7.07)$ & $(9.29)$ \\
EMPRATE & 57.84 & 56.54 & 59.11 \\
& $(5.99)$ & $(5.57)$ & $(6.14)$ \\
Family Poverty Rate & 15.49 & 17.16 & 13.85 \\
& $(6.10)$ & $(6.31)$ & $(5.44)$ \\
Total Families & 1726248 & 577051 & 1149197 \\
Suburban Counties & 30 & 15 & 15 \\
MSA Counties & 38 & 21 & 17 \\
Total Counties & 159 & 79 & 80 \\
& & & \\
\hline
\end{tabular}

higher in Plantation Belt counties than in counties located outside the Plantation Belt. Also, there tends to be less income variation between counties in the Plantation Belt than between counties located outside the Plantation Belt, as shown by the smaller standard deviation of average income for the Plantation Belt counties. Fifth, counties in the Plantation Belt tend to have a higher level of income inequality than counties located outside the Plantation Belt, as indicated by the larger mean Gini coefficient for Plantation Belt counties. 


\section{ECONOMETRIC RESULTS}

Four different versions of equation 1 are estimated and the results are reported in Table 2. Model 1, the most basic model, includes only the two location variables, SUBURBAN and PLANBELT. In Model 2, the variable that measures per capita family income, INCOME, is added, which allows the direction of the relationship between economic development and income inequality to be determined. In Model 3, the variables measuring the demographic, education, and labor force characteristics are added. In Model 4, an interaction term between the percent of the population that is Black and the Plantation Belt dummy variable is added. The inclusion of this variable yields an indication of whether the racial composition of a county's population has a different effect on income inequality in Plantation Belt counties than in counties located outside the Plantation Belt.

TABLE 2

OLS Regression Results of Inequality Models

\begin{tabular}{lrrrr}
\hline \hline VARIABLE & Model 1 & Model 2 & Model 3 & Model 4 \\
\hline SUBURBAN & $-505.77^{\mathrm{a}}$ & $-496.52^{\mathrm{a}}$ & $-161.75^{\mathrm{b}}$ & $-150.48^{\mathrm{a}}$ \\
& $(7.28)$ & $(5.95)$ & $(2.48)$ & $(2.33)$ \\
PLANBELT & $200.69^{\mathrm{a}}$ & $199.38^{\mathrm{a}}$ & -80.70 & 69.36 \\
& $(3.69)$ & $(3.63)$ & $(1.63)$ & $(0.78)$ \\
INCOME & & -.0010 & $.0175^{\mathrm{a}}$ & $.0172^{\mathrm{a}}$ \\
& & $(0.20)$ & $(3.09)$ & $(3.07)$ \\
BLACK & & & 2.84 & $5.49^{\mathrm{b}}$ \\
& & & $(0.93)$ & $(1.66)$ \\
FEMALE & & & $22.91^{\mathrm{a}}$ & $24.21^{\mathrm{a}}$ \\
& & & $(2.80)$ & $(2.99)$ \\
EDUCSTD & & & $538.87^{\mathrm{a}}$ & $560.76^{\mathrm{a}}$ \\
& & & $(4.47)$ & $(4.69)$ \\
MEANEDUC & & & $-104.50^{\mathrm{c}}$ & $-119.74^{\mathrm{b}}$ \\
& & & $(1.51)$ & $(1.74)$ \\
EMPRATE & & & $-23.34^{\mathrm{a}}$ & $-22.85^{\mathrm{a}}$ \\
& & & $(3.98)$ & $(3.93)$ \\
MANUFAC & & & $-10.02^{\mathrm{a}}$ & $-9.65^{\mathrm{a}}$ \\
& & & $(2.81)$ & $(2.74)$ \\
INTPLAN & & & $-5.66^{\mathrm{b}}$ \\
& & & $.683)$ \\
R-squared & & & .696 \\
\hline
\end{tabular}

The absolute value of the t-statistics is shown in parenthesis.

All coefficients are scaled to E-4.

a, b, and c denote significance at the $.01, .05$, and .10 level, respectively. 
The suburban location dummy variable, SUBURBAN, has a negative and statistically significant (at the .01 level) effect on income inequality in all four equations, indicating that counties that are located in the suburban area of an MSA tend to have less income inequality than counties that contain the central city of an MSA or that are located in a nonmetropolitan area, ceteris paribus. The coefficient on PLANBELT is statistically significant (at the .01 level) and positive in Model 1 and Model 2, indicating that counties located in the Plantation Belt have more income inequality than counties located outside the Plantation Belt, ceteris paribus. This result reinforces the implications of the pattern that is revealed in an ordered ranking of Georgia's 159 counties by the Gini coefficient. A ranking of Georgia's counties by the Gini coefficient indicates that of the 40 counties with the smallest Gini coefficient (i.e., the most equal distribution of family income), 14 are located in the Plantation Belt and 26, outside. At the other extreme, of the 40 counties with the largest Gini coefficient, 29 are located in the Plantation Belt and 11 are located outside. This ranking indicates that counties with a relatively high Gini coefficient tend to be concentrated in the Plantation Belt and that counties with a relatively low Gini coefficient tend to be concentrated outside the Plantation Belt.

As the demographic, education, and economic variables are introduced into the equation (Model 3, and Model 4), the coefficient on PLANBELT becomes statistically insignificant or has the wrong sign. This suggests that much of the higher income inequality experienced by Plantation Belt counties is probably caused by the demographic characteristics of Plantation Belt counties, rather than by being located in the Plantation Belt, per se. Two of the major differences between counties in the Plantation Belt and counties located outside the Plantation Belt are related to demographic characteristics. Specifically, Plantation Belt counties tend to have a proportionately larger Black population and proportionately more families headed by a female (with no husband present). Once these demographic characteristics are controlled for, as they are in Model 3 and Model 4, the strength of the coefficient on PLANBELT substantially diminishes.

The two demographic variables, BLACK and FEMALE, are generally found to significantly and positively affect income inequality. FEMALE has a statistically significant effect (at the .01 level) on income inequality in both models, and BLACK has a statistically significant effect (at the .05 level) in Model 4 . These results indicate that income inequality is higher in those counties that have a population with a relatively large percentage of blacks, and is higher in those counties that have a relatively large percentage of families headed by a female (with no husband present), ceteris paribus. The effect of FEMALE on income inequality is substantially larger than the effect of BLACK, however, since the coefficient on FEMALE is about four times as large as the coefficient on BLACK. 
The two education variables, the mean education of the county's 25-year-old and older population (MEANEDUC) and the standard deviation of the educational attainment of the county's 25-year-old and older population (EDUCSTD), are both found to be a significant determinant of income inequality in this study. The regression results indicate that those counties having a population with a relatively high average educational attainment have a lower level of income inequality, and that those counties having a population where the residents have relatively similar levels of educational attainment (i.e., a low standard deviation) have a lower level of income inequality, ceteris paribus.

The percent of a county's working population that is employed in manufacturing, MANUFAC, also affects the Gini coefficient in a county. The negative coefficient on MANUFAC indicates that as the percent of a county's working population that is employed in manufacturing increases, income inequality in the county decreases. In addition, EMPRATE, the percent of the 16-year-old and older population that is employed, is found to have a negative and statistically significant effect on income inequality.

Unlike many previous studies, which find that the income inequality in a region decreases as average income increases, this study finds some evidence that family income inequality in a region increases as per capita family income increases, based on the positive coefficient on INCOME in Model 3 and Model 4. It is not clear why income inequality is not affected by per capita family income in the manner found in most other studies. One possibility is that the relationship between income inequality and average family income is sensitive to the geographic unit being considered. A stronger relationship between income inequality and average family income may exist at the state level than the county/parish level, for example, or a stronger relationship may exist at the national level than at the state level. Heretofore, most studies that have found a strong negative relationship between income inequality and per capita income in the United States have used states as the unit of observation. Only a limited number of studies have employed counties/parishes, which typically encompass a relatively small geographic area, as the unit of observation (e.g., Farbman 1973 and Rice and Sale 1975); and those studies have reported mixed results regarding the effect of average family income on income inequality.

In Model 4, an interaction term, INTPLAN, is introduced that examines the interaction between the percent of a county's population that is Black and whether the county is located in the Plantation Belt. The coefficient on this variable is negative and statistically significant (at the .05 level), indicating that as the percentage of the population that is Black increases, the distribution of income becomes more equal in Plantation Belt counties. Since the coefficient on INTPLAN is slightly larger in absolute value than the coefficient on BLACK, there is a very 
slight negative relationship between the percent of the population that is Black and the Gini coefficient in Plantation Belt counties. The effect of racial composition on income inequality is therefore much stronger in counties located outside the Plantation Belt than in counties in the Plantation Belt. One possible reason for this result is that because of the historical development, Blacks are more integrated into the economy of counties in the Plantation Belt.

\section{SUMMARY AND CONCLUSION}

Using data for Georgia's 159 counties, this paper determines which factors affect family income inequality. Among the factors included in the study are the average family income in the county, the percent of the population that is Black, the percent of the families that are headed by a female, the educational characteristics of the county's population, the employment characteristics of the county's population, and the locational characteristics of the county. The primary focus of the paper is on the extent to which location in Georgia's Plantation Belt, a 79-county region, affects family income inequality in a county. Additionally, the paper examines whether a proportionately large Black population has a stronger effect on income inequality in Plantation Belt counties than in counties located outside the Plantation Belt.

While several previous studies have found evidence that income inequality in a region decreases as per capita income increases, the results of this study do not find support for these findings. On the contrary, this study finds evidence that family income inequality in a county may actually increase as the mean family income in the county increases, as suggested by the positive and statistically significant coefficient on the INCOME coefficient in Models 3 and 4.

Demographic factors, such as the percent of the population that is Black and the percent of families headed by a female (with no husband present), and the educational characteristics of a county's population, are found to significantly affect income inequality in a county. Further, the occupational characteristics of a county's employed population and the percent of the county's working age population that is employed are both found to significantly affect income inequality. Also, the locational characteristics of a county are found to significantly affect income inequality. This study finds that suburban counties in MSAs have a lower level of income inequality than nonMSA counties and MSA counties containing central cities, and finds some evidence that Plantation Belt counties have a higher level of income inequality than counties located outside the Plantation Belt. 
Perhaps the most important finding of the study is that the racial composition of a county's population, coupled with location in the Plantation Belt, is an important determinant of income inequality in a county. This study finds strong evidence that Plantation Belt counties with a relatively large Black population have less income inequality than non-Plantation Belt counties with a similarly large black population, ceteris paribus. Apparently, due to some unexplained institutionalized social and cultural characteristics, family income in counties with a relatively large black population is more equally distributed inside Georgia's Plantation Belt than outside the Plantation Belt.

\section{ENDNOTES}

1. The geographic definition of the Georgia's Plantation Belt is provided by Bartley (1990). An alternative geographic definition is provided in Hahn (1983), p. 7. Using Bartley's definition, the Georgia Plantation Belt consists of 79 contiguous counties. Using Hahn's definition, the Plantation Belt consists of 69 contiguous counties, all of which are part of the Plantation Belt as defined by Bartley. The ten counties excluded from Hahn's Plantation Belt are located along the periphery of Bartley's Plantation Belt.

2. The existence of a "Plantation Belt" is not peculiar to Georgia. The U.S. Census Bureau (1916), in a study of plantation farming, defined a Plantation Belt of 325 roughly contiguous counties that covered parts of eleven Southern states, extending from southern Virginia to eastern Texas. The Census Bureau Plantation Belt covers a significant portion of Texas, Louisiana, Arkansas, Mississippi, Alabama, Georgia, South Carolina, and North Carolina. While not completely equivalent to the Plantation Belt defined by Bartley (1990), the Georgia portion of the Census Bureau Plantation Belt follows the same general pattern as Bartley's Plantation Belt.

3. There is no universal agreement on how much cotton had to be grown in an area or how large the slave population of an area had to be during the pre-Civil War period to warrant inclusion in the Plantation Belt. As a result, there are slight differences in the geographic definition of various Plantation Belts. The three major definitions of the Plantation Belt, Bartley (1990), Hahn (1978), and U.S. Bureau of the Census (1916) are slightly different from each other.

4. Although agriculture existed outside the Plantation Belt regions of Georgia and the South, there were significant differences between the agricultural characteristics in the Plantation Belt region and agricultural characteristics outside the Plantation Belt region. Wright (1986), for example, notes that the small farmers in the Plantation Belt region limited their non-cash crops to corn and 
moved into cotton as they acquired slaves. In the region outside the Plantation Belt farmers practiced a more diversified method of farming (p. 107).

5. Mandle (1978) defines a plantation economy as "one in which profit-maximizing agricultural landowners depend upon some mobilizing mechanism, not simply the operation of a free labor market, to satisfy the need of their farms for disciplined, unskilled workers in large numbers" (p.12).

\section{REFERENCES}

Aigner, D. J., and A. J. Heins. "On the Determinants of Income Inequality." American Economic Review 57 (1967): 175-184.

Amos, Orley. "Substate and SMSA Personal Income Inequality and Regional Development." The Review of Regional Studies 16 (1986): 23-30. "Unbalanced Regional Growth and Regional Income Inequality in the Latter Stages of Development." Regional Science and Urban Economics 18 (1988): 549-566.

Bartley, Numan. The Creation of Modern Georgia. 1990. (Athens, GA: The University of Georgia Press).

Bishop, John A., John P. Formby, and Paul D. Thistle. "Changes in US Earnings Distributions in the 1980s." Applied Economics 23 (1991): 425-434.

Bradbury, Katharine. "The Changing Fortunes of American Families in the 1980s." New England Economic Review July/August 1990: 25-40.

Braun, Denny. "Multiple Measurements of U.S. Income Inequality." The Review of Economics and Statistics 70 (1988): 398-405.

Brem, Natalie, Garey Durden, and Patricia Gaynor. "The Effect of Government Employment on Income Inequality Overall and in the South: Evidence for Congressional District Data." The Review of Regional Studies 19 (1989): 4047.

Card, David, and Richard B. Freeman. "Small Differences that Matter: Canada vs. the United States." in Working Under Different Rules. edited by Richard B. Freeman. 1994. (New York: The Russell Sage Foundation).

Danziger, Sheldon. "Determinants of the Level and Distribution of Family Income in Metropolitan Areas, 1969." Land Economics 52 (1976): 467-478.

Durden, Garey, and Ann Schwarz-Miller. "The Distribution of Individual Income in the U.S. and Public Sector Employment." Social Science Quarterly 63 (1982): 39-47.

Farbman, Michael. "Income Concentration in the Southern United States." The Review of Economics and Statistics 55 (1973): 333-340. 
Gunther, William, and Charles Leathers. "Trends in Income Inequality in the South, 1950 to 1970." Growth and Change 6 (1975): 19-22.

Hahn, Steven. The Roots of Southern Populism: Yeoman Farmers and the Transformation of the Georgia Upcountry, 1850-1890. 1983. (Oxford: Oxford University Press).

Husted, Thomas. "Changes in State Income Inequality from 1981 to 1987." The Review of Regional Studies 21 (1991): 249-260.

Institute of Community and Area Development. The Atlas of Georgia. 1986. (Athens, GA: The University of Georgia).

Kuznets, Simon. "Economic Growth and Income Inequality." American Economic Review 45 (1955): 1-28.

Levernier, William, Mark D. Partridge, and Dan S. Rickman. "Variation in State Income Inequality: 1960-1990." International Regional Science Review 18 (1995): 355-378.

Long, James E., David W. Rasmussen, and Charles T. Haworth. "Income Inequality and City Size." The Review of Economics and Statistics 59 (1977): 244-246

Mandle, Jay R. The Roots of Black Poverty: The Southern Plantation Economy After the Civil War. 1978. (Durham, NC.: Duke University Press).

Maxwell, Nan. "Demographic and Economic Determinants of United States Income Inequality." Social Science Quarterly 70 (1989): 245-264.

Nissan, Edward, and George Carter. "Income Inequality Across Regions Over Time." Growth and Change 24 (1993): 303-319.

Partridge, Mark D., Dan S. Rickman, and William Levernier. "Trends in U.S. Income Inequality: Evidence from a Panel of States." Quarterly Review of Finance and Economics 36 (1996): 17-37.

Renkow, Mitch. "Income Non-Convergence and Rural-Urban Earnings Differentials: Evidence from North Carolina." Southern Economic Journal 62 (1996): 1017-1028.

Rice, G., and Tom Sale. "Size Distribution of Income in Louisiana and Other Southern States." Growth and Change 6 (1975): 26-33.

U.S. Bureau of the Census. Plantation Farming in the United States. 1916. (Washington, DC.: U.S. Government Printing Office). 1990 Census of Population :Georgia.. STF3A-14 CD-ROM.

Wright, Gavin. Old South, New South: Revolutions in the Southern Economy Since the Civil War. 1986. (New York: Basic Books, Inc.). 